Gut, 1962, 3, 149

\title{
The blood volume and plasma protein levels before and after gastrectomy ${ }^{1}$
}

\author{
ALEXANDER SWAN, GEOFFREY T. ALLEN, AND \\ NORMAN C. TANNER
}

From St. James's Hospital, Balham, London

EDITORIAL SYNOPSIS This paper is a survey of a series of 185 plasma volume estimations carried out on 75 gastric surgical patients before and after operation at St. James's Hospital in 1958-59. In the majority of cases serum proteins were also measured. The purpose of this work was to study the effects of gastric operations, and especially of partial gastrectomy, on patients' blood volume, the oxygen-carrying capacity of the blood as measured by the total circulating red cell volume, and serum protein content.

The importance of plasma volume and of total circulating red cell volume in assessing a patient's pre-operative condition, operative blood loss, and post-operative state is becoming widely accepted in surgical practice. There have, moreover, been indications in the literature (Clark, Nelson, Lyons, Mayerson, and DeCamp, 1947; Mallet-Guy, Devic, and Grangeon, 1950; Mallet-Guy, Devic, and Ricard, 1954; Mallet-Guy, Ricard, and Corréard, 1955) that a persistently defective blood volume may account for retardation of recovery after such operations and for some of the manifestations of post-operative ill-health, if not for the dumping syndrome itself.

The present account of the work falls naturally into two main sections: 1 The assessment of patients' pre-operative state in relation to body weight, blood volume, and plasma proteins, and 2 , their postoperative changes.

\section{METHODS}

Of the numerous existing methods of blood volume estimation we selected the dye dilution method for its relative simplicity and low cost, making it readily available for routine use in any hospital. For the same reason we avoided such time-consuming refinements as extraction procedures (Campbell, Frohman, and Reeve, 1958; Hobsley and Dew, 1958; Jarnum, 1959; Lawrence and Walters, 1959) or attempts at overcoming the effects of

'This project was financed by a grant from the South-West Metropolitan Regional Hospital Board.

The preliminary account of this work was given in the form of a paper read before the Joint Meeting of the Association of Clinical Pathologists and the Association of Clinical Biochemists on 1 October 1960. lipaemia by multiple colorimetric readings at various wavelengths (Davis and Isenberg, 1953; Hamilton, 1958; Gibson and Evans, 1937a); heavily opalescent specimens were discarded. We used Geigy blue $536 \mathrm{med}^{2}$. which has the same structural formula as Evans blue. The details of the method used are given in our previous publication (Swan, Allen, and Tanner, 1959).

Two hundred and eighty-three plasma volume estimations were carried out using this method on 121 persons. Serum protein levels were determined by the biuret method, and the separation of albumin from globulins was achieved by sodium sulphate precipitation. Plasma volume measurements, and when possible serum protein estimations, were performed three times on each available and willing patient of the series of 75 cases, i.e., shortly before the operation, nine to 10 days after it, and again after an interval of from six to nine months. In this series, $71 \%$ of cases were men and $29 \%$ women. Their ages varied from 79 to 17 years, with a peak in the fifth and sixth decades.

On the morning of blood volume estimation the patients were instructed to have no breakfast. The first post-operative estimation was done in all cases except two ${ }^{3}$ at least five days after all parenteral fluids had been stopped.

\section{THE PRE-OPERATIVE STATE}

BODY WEIGHT Body weight was recorded and the height measured in 37 cases of partial gastrectomy, in 10 cases of vagotomy with gastro-enterostomy, and in six cases of pyloroplasty. The normal value of body weight for each individual case was obtained

'A sample of the dye was kindly supplied by Geigy Pharmaceutical Co., Ltd.

'In one case the interval was four days and in the other three days. 
TABLE I

PRE-OPERATIVE AND NORMAL BODY WEIGHTS COMPARED

\begin{tabular}{|c|c|c|c|c|c|}
\hline & \multicolumn{3}{|c|}{ Partial Gastrectomy (37 Cases) } & \multirow{2}{*}{$\begin{array}{l}\text { Vagotomy } \\
\text { (10 Cases) }\end{array}$} & \multirow{2}{*}{$\begin{array}{l}\text { Pyloroplasty } \\
\text { (6 Cases) }\end{array}$} \\
\hline & $\begin{array}{l}\text { Gastric and } \\
\text { Duodenal } \\
\text { Ulcer } \\
\text { (37 Cases) }\end{array}$ & $\begin{array}{l}\text { Gastric } \\
\text { Ulcer } \\
\text { (12 Cases) }\end{array}$ & $\begin{array}{l}\text { Duodenal } \\
\text { Ulcer } \\
\text { (25 Cases) }\end{array}$ & & \\
\hline $\begin{array}{l}\text { Mean pre-operative body weight (kg.) } \\
\text { Mean normal body weight (kg.) } \\
\text { Difference of the means } \\
\text { Difference of the means as percentage of mean normal } \\
\text { Mean pre-operative weight as percentage of mean normal weight }\end{array}$ & $\begin{array}{r}59.84 \\
63.93 \\
-4.09 \\
-6.50 \\
93.50\end{array}$ & $\begin{array}{r}50 \cdot 84 \\
60.90 \\
-10 \cdot 06 \\
-16.50 \\
83.50\end{array}$ & $\begin{array}{r}64 \cdot 18 \\
65 \cdot 38 \\
-1 \cdot 20 \\
-1 \cdot 84 \\
98 \cdot 16\end{array}$ & $\begin{array}{r}61 \cdot 79 \\
66 \cdot 35 \\
-4 \cdot 56 \\
-6 \cdot 90 \\
93 \cdot 10\end{array}$ & $\begin{array}{r}68 \cdot 97 \\
67 \cdot 83 \\
+1 \cdot 14 \\
+1 \cdot 70 \\
101 \cdot 70\end{array}$ \\
\hline
\end{tabular}

from the tables of heights and weights (Life Extension Institute of New York City), taking into consideration the patient's height, sex, and age. The results are summarized in Table $I$.

Comparison of the mean values of the actual pre-operative and normal body weights (Table I) shows, in the partial gastrectomy group, a mean deficit of $4.09 \mathrm{~kg}$. or $6.5 \%$ of the mean normal weight. The statistical probability (P) of such a difference between the means occurring by chance is $\mathbf{P}=\mathbf{0 . 1 3 5}$, which is much greater than the usually accepted upper limit of probability $(P=0.05)$. The difference between these two means cannot, therefore, be regarded as significant. The partial gastrectomy group, however, is composed of two types of cases, those with gastric ulcer (12 cases) and those with duodenal ulcer ( 25 cases). It is well known that sufferers from chronic gastric ulcer tend to be underweight, due to aggravation of the pain after taking food. whereas patients with chronic duodenal ulcer maintain their body weight satisfactorily, for in their case ingesting food tends to alleviate pain. The findings in our series confirm this impression. The mean deficit of body weight in the gastric ulcer group is $-10.06 \mathrm{~kg} .(-16.50 \%)$ and is statistically significant ( $P$ being equal approximately to 0.002 ). In the duodenal ulcer group of the partial gastrectomy series, on the other hand, there is practically no weight deficit $(-1 \cdot 20 \mathrm{~kg}$., or $-1 \cdot 84 \%)$. Further, 10 cases of duodenal ulcer in the vagotomy with gastroenterostomy group show a somewhat greater $(-4.56 \mathrm{~kg}$. , or $-6.90 \%)$ but still statistically insignificant $(P=0.36)$ deficit. The small group of six cases of pyloroplasty consisting of patients in whom no peptic ulceration was discovered at operation showed no deficit of mean body weight; there was, on the contrary, a slight excess $(+1 \cdot 14 \mathrm{~kg}$., or $+1 \cdot 70 \%$ ).

BLOOD VOLUME The pre-operative state in relation to plasma volume, total blood volume, and total circulating red cell volume was evaluated in 37 cases of partial gastrectomy, in 10 cases of vagotomy, and in six cases of pyloroplasty, by comparing in each individual case the pre-operative values of plasma, blood, and total circulating red cell volume with the respective normal values. The latter were calculated in each case from the patient's normal (tabular) weight and normal values per kilogram of body weight of plasma volume $(42 \mathrm{ml} . / \mathrm{kg}$.), blood volume $(70 \mathrm{ml} . / \mathrm{kg}$.), and total red cell volume $(28 \mathrm{ml} . / \mathrm{kg}$.). These normal values were based on estimations done on 15 persons whose haemoglobin was within normal limits and body weight did not deviate more than $15 \%$ from the respective normal (tabular) values. They agree reasonably well with the figures similarly adopted as normal by some other workers using the dye method (Gibson and Evans, 1937b; Gibson, Peacock, Seligman, and Sack, 1946; Inkley, Krieger, and Brooks, 1953). Separate sets of normal standards for women and old people were deemed unnecessary. Blood volume deficit (or excess) was obtained by subtracting a patient's estimated blood volume from the theoretical ('ideal') normal volume based on his tabular normal weight. In common with other investigators (Clark et al., 1947; Schrevel, Lammerant, and Visscher, 1955; Williams and Parsons, 1958), we consider it incorrect to calculate blood volume deficits on the basis of patients' actual weights, for in a depleted person the latter is pathologically reduced. This procedure also eliminates the necessity for assessing each subject's degree of obesity (Hicks, Hope, Turnbull, and Verel, 1956). The results are summarized in Table II.

From Table II it may be seen that in the partial gastrectomy group there was a considerable deficit of the total blood volume and of both its component plasmas, and total red cell volume, the plasma volume mean deficit being 0.42 litre $(15.30 \%$ of the mean normal), and that of total red cell volume 0.2321 . (12.71\% of the mean normal). These differences of the mean were found to be statistically highly significant; thus $\mathbf{P}$ plasma volume was less than 0.001 and $\mathbf{P}$ total red cell volume $=0.0025$. The difference between the gastric and duodenal ulcer cases within the partial gastrectomy group was 
TABLE II

PRE-OPERATIVE STATE OF PLASMA VOLUME, TOTAL BLOOD VOLUME, AND TOTAL RED CELL VOLUME

$\begin{array}{lllll}\text { Mean Pre- } & \text { Mean Normal } & \text { Difference of } & \text { Difference of } & \text { Pre-operative } \\ \text { operative Volumes } & \text { Volumes } & \text { Means }{ }^{1} & \text { Means as \% of } & \text { Mean as \% of Mean } \\ \text { (l.) } & (l .) & (l .) & \text { Mean Normal } & \text { Normal }\end{array}$

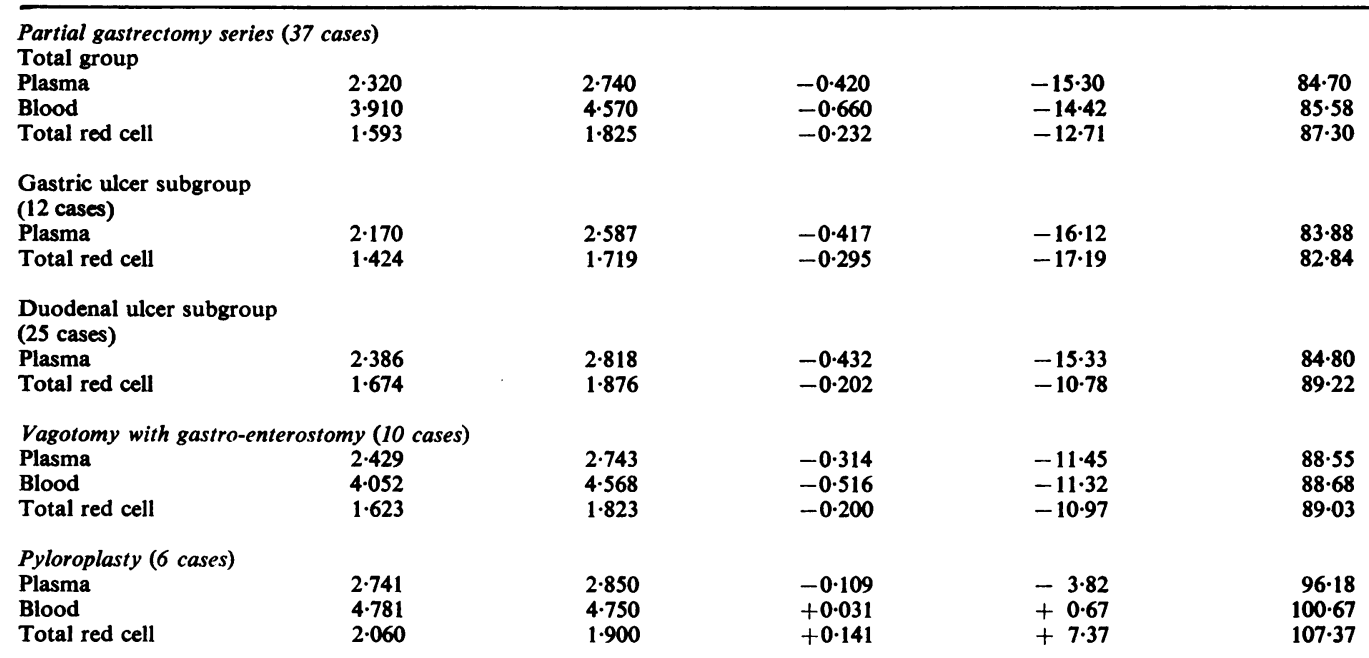

'The difference is regarded as negative if the pre-operative volume is smaller than the normal volume (a deficit) and positive if it exceeds the normal volume.

found to be negligible in respect of the plasma volume deficit (the mean plasma volume deficit in the gastric ulcer group being $16 \cdot 12 \%$ of the mean normal, and that in the duodenal ulcer group $15.33 \%$ ). In respect of total red cell volume, the difference between the gastric ulcer and duodenal ulcer cases proved to be greater $(0.2951$., or $17.19 \%$, and 0.2021 ., or $10 \cdot 78 \%$ respectively) but still statistically not significant $(P=0.06)$. Putting it another way, even the smallest of the four, plasma and total red cell volume deficits, that of total red cell volume in the duodenal ulcer group was in itself statistically significant $(P=0.03)$. It was therefore regarded as superfluous to subdivide the partial gastrectomy series, and cases of gastric and duodenal ulcers were, for purposes of blood volume, treated together.

The mean values in the vagotomy group showed blood volume deficits similar to those of the partial gastrectomy series, whereas in the pyloroplasty group the mean volumes were found to be essentially normal.

STATE OF ANAEMIA A deficit in total red cell volume is synonymous with anaemia. The total red cell circulating volume is a better index of anaemia than either haemoglobin $(\mathrm{Hb})$ or packed cell volume (P.C.V.) by itself, for it measures the total oxygencarrying capacity of the circulating blood and not just the amount of haemoglobin or of red cells per unit volume of blood. In Table III a comparison is made of the mean values of Hb, P.C.V., and total red cell volume for 37 cases admitted for partial gastrectomy. It shows that the true state of anaemia, as measured by the deficit in total red cell volume,

\section{TABLE III}

PRE-OPERATIVE STATE OF ANAEMIA AS MEASURED BY HAEMOGLOBIN, PACKED CELL VOLUME, AND TOTAL CIRCULATING RED CELL VOLUME

\begin{tabular}{|c|c|c|c|}
\hline Partial Gastrectomy Series (37 Cases) & $\begin{array}{l}\text { Hb } \\
\text { (Haldane Scale) }\end{array}$ & $\begin{array}{l}\text { Packed Cell } \\
\text { Volume }(\%)\end{array}$ & $\begin{array}{l}\text { Total Red Cell } \\
\text { Volume }(l .)\end{array}$ \\
\hline $\begin{array}{l}\text { Mean pre-operative values } \\
\text { Mean normal values } \\
\text { Difference of the means } \\
\text { Same, as percentage of respective mean normal } \\
\text { Pre-operative mean as percentage of respective mean normal }\end{array}$ & $\begin{array}{l}13.33 \mathrm{~g} / 100 \mathrm{ml} \\
14.60 \mathrm{~g} / 100 \mathrm{ml} \\
-1.27 \mathrm{~g} . / 100 \mathrm{ml} \\
-8 \cdot 70 \\
91.30\end{array}$ & $\begin{array}{r}46 \cdot 35 \\
47 \cdot 00 \\
-0 \cdot 65 \\
-1 \cdot 38 \\
98 \cdot 62\end{array}$ & $\begin{array}{r}1 \cdot 593 \\
1 \cdot 825 \\
-0 \cdot 232 \\
-12 \cdot 71 \\
87 \cdot 30\end{array}$ \\
\hline
\end{tabular}


in the present series was more severe than either the mean $\mathrm{Hb}$ or mean packed cell volume figures indicate.

The mean total red cell volume deficit was, in the partial gastrectomy group, $\mathbf{0 . 2 3 2}$ litre; this, at normal packed cell volume level $=47 \mathrm{vol}$. $\%$, is equivalent to 0.494 litre of whole blood. Allowing for the volume of the glucose-citrate anticoagulant mixture at the rate of $120 \mathrm{ml}$. for every $540 \mathrm{ml}$. of total volume, a figure of 0.635 litre is obtained, which expresses the total red cell volume deficit in terms of stored blood. Since a 'pint' of stored blood is supposed to contain $540 \mathrm{ml}$. of the blood-anticoagulant mixture, the mean pre-operative deficit is, in the partial gastrectomy group, equivalent to $1 \cdot 2$ pints of stored blood. The total red cell volume deficit in the vagotomy group is of a similar magnitude.

Thus, in terms of mean values, patients with chronic peptic ulcer admitted for operation tended to have a red cell deficit that could be corrected by a transfusion of from 1 to $1 \frac{1}{2}$ pints of stored blood. However, for clinical purposes the mean values are misleading, for there may be considerable individual variation. Thus, of our 37 cases, eight (about $22 \%$ ) showed no deficit in total red cell volume; on the other hand, in seven cases (about 19\%) this deficit exceeded the equivalent of $2 \frac{1}{2}$ pints of stored blood. A pre-operative blood volume estimation is therefore indicated in every patient admitted with chronic peptic ulcer. The unreliability of haemoglobin and packed cell volume as measures of anaemia was discussed in our previous publication (Swan et al., 1959).

SERUM PROTEINS Serum proteins were estimated preoperatively in 30 cases of partial gastrectomy, in eight cases of vagotomy with gastro-enterostomy, and in five cases of pyloroplasty. The resulting mean values of their concentrations (g./100 ml.) are collected in Table IV and compared with the mean normal values adopted in this laboratory. From Table IV it can be seen that whereas the mean total protein concentration in the partial gastrectomy series is practically identical with the adopted mean normal figure, its two components, the albumin and globulins, tend to diverge in opposite directions, the mean value for the albumin being at the lower limit of its normal range and that for the globulins at the upper limit of their normal range. In fact, the serum albumin concentration was below the lower normal limit in 14 out of 30 cases, and that of the serum globulins exceeded the upper normal limit in 15 out of 30 cases. The picture is similar in the vagotomy group. On the other hand, in the pyloroplasty group (patients without peptic ulcer), there was no albumin deficit, although the globulins, for reasons that are not clear, were found to be rather high. However, since this group contained only five cases no conclusions were possible.

The partial gastrectomy series consisted, as before, of both chronic gastric (14 cases) and chronic duodenal (16 cases) ulcer cases. The mean values of serum protein concentrations for these two groups are tabulated in Table IVa and compared with those for the whole partial gastrectomy series. Although the results for the gastric and duodenal ulcer groups in relation to total serum proteins are practically identical, those for serum albumin and serum proteins show differences between the means in opposite directions. The difference of the means for serum globulins, when expressed as a percentage of the mean for the whole series of partial gastrectomy, is larger than that for serum albumin. Statistically, however, even this larger difference is not significant $(P>0 \cdot 2)$. Therefore, gastric and duodenal ulcer cases were regarded as a single group.

TABLE IV

MEAN VALUES OF SERUM PROTEIN CONCENTRATIONS COMPARED WITH ADOPTED MEAN NORMAL VALUES

\begin{tabular}{|c|c|c|c|c|c|}
\hline & $\begin{array}{l}\text { Mean Pre- } \\
\text { operative Values } \\
(\mathrm{g} . / 100 \mathrm{ml} .)\end{array}$ & $\begin{array}{l}\text { Adopted Mean } \\
\text { Normal Values } \\
(\mathrm{g} . / 100 \mathrm{ml} .)\end{array}$ & $\begin{array}{l}\text { Difference of the } \\
\text { Means } \\
(\mathrm{g} . / 100 \mathrm{ml} .)\end{array}$ & $\begin{array}{l}\text { Difference of the } \\
\text { Means as } \% \text { of } \\
\text { Mean Normal }\end{array}$ & $\begin{array}{l}\text { Pre-operative Mean } \\
\text { as \% of Adopted } \\
\text { Mean Normal }\end{array}$ \\
\hline \multicolumn{6}{|c|}{ Partial gastrectomy series (30 cases) } \\
\hline Total proteins & $7 \cdot 15$ & $7 \cdot 20$ & -0.05 & -0.70 & $99 \cdot 30$ \\
\hline Albumin & $4 \cdot 60$ & $5 \cdot 20$ & -0.60 & $-11 \cdot 50$ & $88 \cdot 50$ \\
\hline Globulins & $2 \cdot 55$ & $2 \cdot 00$ & +0.55 & $+27 \cdot 50$ & $127 \cdot 50$ \\
\hline \multicolumn{6}{|c|}{ Vagotomy with gastroenterostomy (8 cases) } \\
\hline Albumin & $4 \cdot 79$ & $5 \cdot 20$ & -0.41 & $-7 \cdot 88$ & $92 \cdot 12$ \\
\hline Globulins & $2 \cdot 635$ & $2 \cdot 00$ & +0.635 & $+31 \cdot 77$ & $131 \cdot 77$ \\
\hline \multicolumn{6}{|c|}{ Pyloroplasty (5 cases) } \\
\hline Total proteins & $7 \cdot 96$ & $7 \cdot 20$ & +0.76 & +10.56 & $110 \cdot 56$ \\
\hline Albumin & $5 \cdot 32$ & $5 \cdot 20$ & +0.12 & $\begin{array}{r}+10 \\
+\quad 2 \cdot 11\end{array}$ & $102 \cdot 11$ \\
\hline Globulins & $2 \cdot 64$ & $2 \cdot 00$ & +0.64 & +32.00 & 132.00 \\
\hline
\end{tabular}


TABLE IVa

MEAN VALUES OF SERUM PROTEIN CONCENTRATIONS IN GASTRIC AND DUODENAL ULCER GROUPS OF PARTIAL GASTRECTOMY SERIES COMPARED

\begin{tabular}{|c|c|c|c|c|c|}
\hline & Gastric Ulcer & Duodenal Ulcer & $\begin{array}{l}\text { Difference of the } \\
\text { Means }\end{array}$ & $\begin{array}{l}\text { Mean Values } \\
\text { for Whole Partial } \\
\text { Gastrectomy Series }\end{array}$ & $\begin{array}{l}\text { Difference of Means a } \\
\% \text { of Mean of Whole } \\
\text { Partial Gastrectomy } \\
\text { Series }\end{array}$ \\
\hline $\begin{array}{l}\text { Total proteins } \\
\text { Albumin } \\
\text { Globulins }\end{array}$ & $\begin{array}{l}7 \cdot 11 \\
4 \cdot 48 \\
2 \cdot 63\end{array}$ & $\begin{array}{l}7 \cdot 185 \\
4 \cdot 73 \\
2 \cdot 45\end{array}$ & $\begin{array}{l}0.075 \\
0 \cdot 25 \\
0 \cdot 18\end{array}$ & $\begin{array}{l}7 \cdot 15 \\
4 \cdot 60 \\
2 \cdot 55\end{array}$ & $\begin{array}{l}0 \cdot 96 \\
5 \cdot 44 \\
7 \cdot 05\end{array}$ \\
\hline
\end{tabular}

TABLE V

MEAN PRE-OPERATIVE TOTAL CIRCULATING SERUM PROTEIN MASSES IN 25 CASES OF PEPTIC ULCER COMPARED WITH MEAN NORMAL VALUES FROM THE SAME SERIES

\begin{tabular}{|c|c|c|c|}
\hline & Total Proteins & Albumin & Globulins \\
\hline $\begin{array}{l}\text { Pre-operative mean values (g.) } \\
\text { Mean normal values (g.) } \\
\text { Difference of the means (g.) } \\
\text { Same as percentage of mean normal } \\
\text { Probability of such a difference arising by chance (P) } \\
\text { Pre-operative mean as percentage of mean normal }\end{array}$ & $\begin{array}{l}169 \cdot 68 \\
195 \cdot 00 \\
-24 \cdot 32 \\
-12 \cdot 46 \\
0 \cdot 010 \\
\text { (significant) } \\
87 \cdot 54\end{array}$ & $\begin{array}{l}110 \cdot 96 \\
140 \cdot 84 \\
-29 \cdot 88 \\
-21 \cdot 22 \\
<0.001 \\
\text { (highly significant) } \\
78 \cdot 78\end{array}$ & $\begin{aligned} & 58 \cdot 74 \\
& 54 \cdot 12 \\
+ & 4 \cdot 62 \\
+ & 8 \cdot 54 \\
& 0 \cdot 100 \\
\text { (not significant) } & \\
& 108 \cdot 54\end{aligned}$ \\
\hline
\end{tabular}

Total circulating masses of serum proteins were calculated in the same three groups of patients by multiplying the figures of concentrations (in grams per litre) by the respective plasma volume (litres). Comparison with normal figures was, however, possible in only 25 out of 38 cases of peptic ulcer (partial gastrectomy and vagotomy series combined), for which heights, and normal tabular weights, as well as normal plasma volumes, were available.

The mean values and statistical significance of differences of the means are given in Table V. From it one can see that in the present series of 25 cases of peptic ulcer there was pre-operatively a highly significant serum albumin deficit, due partly to a low albumin concentration and partly to reduced plasma volume. The mean total circulating protein mass was also significantly reduced, due to albumin deficit. Serum globulins, however, showed some excess, though not a statistically significant one.

A tendency to hypoalbuminaemia in our peptic ulcer patients before gastrectomy is a finding of some interest. The literature on this subject, unlike that on the serum protein changes following gastrectomy, is very scarce (Badyl'kes and Bygodner, 1957; Conti, Cortinovis, Arisi, and Manzini, 1957) and we could find practically nothing relevant in the English and American journals. The significance of this pregastrectomy hypoalbuminaemia and its suggested (Fauvret, Hartmann, Guénin, and Thiébauld, 1952) relation to anaemia will be discussed in a forthcoming paper.

\section{THE POST-OPERATIVE STATE}

BODY WEIGHT This was measured again six to nine months after operation, in the same three groups of patients as before operation. There was no significant change in comparison with the pre-operative state (Table VI). The gastric ulcer patients remained underweight.

\section{TABLE VI}

LONG-TERM POST-OPERATIVE CHANGES OF BODY WEIGHT

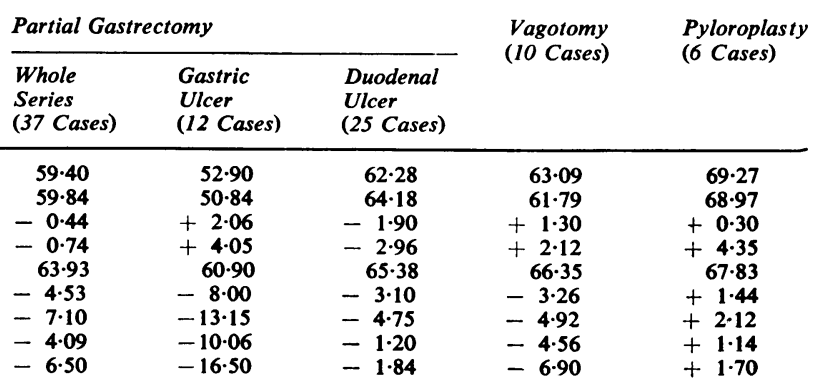


BLOOD VOLUME Blood volume was estimated nine to 10 days after operation and again six to nine months after it. The discussion of the post-operative state is therefore divided into two sections, the immediate effects of operation and long-term results.

Immediate Effects of Operation Results of plasma, blood, and total red cell volume estimations were available for 37 cases of partial gastrectomy operated on without blood transfusion, nine cases of the same operation with blood transfusion, seven cases of vagotomy with gastro-enterostomy, and six cases of pylorcplasty. The mean values are tabulated and compared with the pre-cperative means in Table VII.

As might be expected, there was in all three types of operation done without blood transfusion a postoperative fall in total red cell volume, due to operative blood loss, accompanied by some compensatory plasma volume rise. Nine to ten days after operation, the fall was on the average of the order of 1.3 pints, or roughly, $1 \frac{1}{2}$ pints of stored blood, in those who had undergone partial gastrectomy, 1 pint after vagotomy with gastro-enterostomy, and $\frac{3}{4}$ of a pint after pyloroplasty. Since the fall in total red cell volume was accompanied by some compensatory rise in plasma volume, the resulting total blood volume change bore no relation to the anaemia induced by cperation.

In the group of nine cases of partial gastrectomy done with blood transfusion the post-operative fall in total red cell volume was naturally much smaller than in the non-transfused group $(6 \cdot 34 \%$ of the preoperative level instead of $14 \cdot 23 \%$ ). These patients were given amounts of blood varying from 1 to 3 pints (mean value of 2 pints), either during or immediately after operation. Blood transfusion was given either on account of excessive operative blood loss or other clinical considerations. This group cannot therefore be regarded as comparable to the above non-transfused series of 37 cases.

LONG-TERM EFFECTS The mean values are collected in Table VIII and compared with the pre-operative figures. The partial gastrectomy series is represented by 25 cases operated on without blood transfusion and four cases with blood transfusion, vagotomy by six cases, and pyloroplasty by five.

The general impression is that by six to nine months after operation both the plasma volume and total red cell volume (and therefore blood volume as a whole) tend to return to their pre-operative levels. Individual case figures of the partial gastrectomy series (done without blood transfusion) show that in 15 cases $(60 \%)$ the total red cell volume level reached or exceeded the pre-operative figure, whereas in the remaining $\mathbf{1 0}$ there was some residual deficit. Taking in consideration that the mean pre-operative level of total red cell volume was $12.71 \%$ below normal, one may conclude that the true state of anaemia did not improve after partial gastrectomy. Four patients undergoing partial gastrectomy with blood transfusion, who had received on the average $1 \frac{1}{2}$ pints of blood each, seem to have fared better in this respect (total red cell volume $+8.25 \%$ instead of $-0.20 \%$ in the non-transfused series). With only four cases in the group, however, the significance of this result is very doubtful. Similarly, a long-term mean total red cell volume deficit $(-9.42 \%)$ in the pyloroplasty group is of no significance, for the same reason.

THE DUMPING SYNDROME The symptoms and signs compatible with the diagnosis of the dumping syndrome and persisting for over six months or longer were observed in six patients. Two of them

\section{TABLE VII}

IMMEDIATE POST-OPERATIVE CHANGES OF BLOOD VOLUME

\begin{tabular}{|c|c|c|c|c|}
\hline Volumes (l.) & $\begin{array}{l}\text { Post-operative } \\
\text { Means }\end{array}$ & $\begin{array}{l}\text { Pre-operative } \\
\text { Means }\end{array}$ & $\begin{array}{l}\text { Difference of the } \\
\text { Means }\end{array}$ & $\begin{array}{l}\text { Same as } \% \text { of Pre- } \\
\text { operative Mean }\end{array}$ \\
\hline \multicolumn{5}{|c|}{ Partial gastrectomy without blood transfusion } \\
\hline Plasma & $2 \cdot 653$ & $2 \cdot 543$ & $+0 \cdot 110$ & $+4 \cdot 32$ \\
\hline Blood & $4 \cdot 160$ & $4 \cdot 286$ & $-0 \cdot 126$ & -2.94 \\
\hline Total red cell & 1.495 & $1 \cdot 743$ & -0.248 & $-14 \cdot 23$ \\
\hline \multicolumn{5}{|c|}{ Partial gastrectomy with blood transfusion } \\
\hline Plasma & 3.027 & $2 \cdot 706$ & +0.321 & $+11 \cdot 86$ \\
\hline Blood & 4.579 & $4 \cdot 373$ & +0.206 & $+4 \cdot 71$ \\
\hline Total red cell & $1 \cdot 552$ & 1.657 & -0.105 & -6.34 \\
\hline \multicolumn{5}{|c|}{ Vagotomy with gastro-enterostomy } \\
\hline Plasma & $2 \cdot 717$ & $2 \cdot 631$ & +0.086 & $+3 \cdot 27$ \\
\hline Blood & $4 \cdot 270$ & $4 \cdot 381$ & $-0 \cdot 111$ & $-2 \cdot 54$ \\
\hline Total red cell & $1 \cdot 553$ & $1 \cdot 750$ & -0.197 & $-11 \cdot 26$ \\
\hline \multicolumn{5}{|l|}{ Pyloroplasty } \\
\hline Plasma & 2.975 & $2 \cdot 790$ & +0.185 & +6.63 \\
\hline Blood & $4 \cdot 880$ & $4 \cdot 853$ & +0.027 & +0.55 \\
\hline Total red cell & 1.905 & 2.056 & -0.151 & $-7 \cdot 34$ \\
\hline
\end{tabular}


TABLE VIII

LONG-TERM POST-OPERATIVE BLOOD VOLUME CHANGES

\begin{tabular}{|c|c|c|c|c|}
\hline Volumes (l.) & $\begin{array}{l}\text { Post-operative } \\
\text { Mean Values }\end{array}$ & $\begin{array}{l}\text { Pre-operative } \\
\text { Means }\end{array}$ & $\begin{array}{l}\text { Difference of the } \\
\text { Means }\end{array}$ & $\begin{array}{l}\text { Same as } \% \text { of Pre- } \\
\text { operative Mean }\end{array}$ \\
\hline \multicolumn{5}{|c|}{ Partial gastrectomy without blood transfusion (25 cases) } \\
\hline Plasma & $2 \cdot 594$ & $2 \cdot 380$ & +0.214 & +9.03 \\
\hline Blood & $4 \cdot 184$ & $3 \cdot 972$ & +0.212 & $+5 \cdot 34$ \\
\hline Total red cell & $1 \cdot 588$ & $1 \cdot 591$ & -0.003 & -0.20 \\
\hline \multicolumn{5}{|c|}{ Partial gastrectomy with blood transfusion (4 cases) } \\
\hline Plasma & $2 \cdot 688$ & $2 \cdot 118$ & +0.575 & $+27 \cdot 22$ \\
\hline Blood & $4 \cdot 098$ & $3 \cdot 415$ & +0.683 & +20.00 \\
\hline Total red cell & 1.410 & $1 \cdot 303$ & +0.107 & $+8 \cdot 25$ \\
\hline \multicolumn{5}{|c|}{ Vagotomy with gastro-enterostomy (6 cases) } \\
\hline Plasma & 3.043 & $2 \cdot 740$ & +0.303 & +11.06 \\
\hline Blood & $5 \cdot 053$ & $4 \cdot 650$ & +0.403 & +8.67 \\
\hline Total red cell & $2 \cdot 010$ & 1.910 & $+0 \cdot 100$ & $+5 \cdot 18$ \\
\hline \multicolumn{5}{|c|}{ Pyloroplasty (5 cases) } \\
\hline Blood & $5 \cdot 014$ & 5.000 & +0.014 & +0.28 \\
\hline Total red cell & 1.922 & $2 \cdot 124$ & -0.202 & -9.42 \\
\hline
\end{tabular}

unfortunately were not available for the second post-operative blood volume estimation. Of the four cases fully studied only one showed a persistent blood volume deficit; one patient returned to the pre-operative state in respect of his blood volume, and the remaining two had a rise in both blood volume and total red cell volume compared with the preoperative figures. The mean values of this small group of patients with the dumping syndrome (Table IX) were almost the same as those for the whole partial gastrectomy series. Thus our limited material gives no reason to believe that the dumping syndrome is associated with a persistently reduced blood volume.

If the early post-cibal symptoms are due to a lowered blood volume, it is more likely to be due to a transient post-prandial plasma volume fall, as suggested by Roberts, Randall, Farr, Kidwell, McNeer, and Pack (1954) and later convincingly demonstrated by Le Quesne and his associates (Hobsley and Le Quesne, 1960; Le Quesne, Hobsley, and Hand, 1960).
SERUM PROTEINS The immediate and long-term effects on the serum proteins were studied.

Immediate effects Serum protein levels on the ninth or tenth day after operation were estimated in 30 cases of partial gastrectomy, eight cases of vagotomy with gastro-enterostomy, and five cases of pyloroplasty. In Table $\mathrm{X}$, mean values of concentrations and total circulating masses of serum proteins are given and compared with the respective pre-operative figures.

From Table $\mathbf{X}$ it can be seen that the well known post-traumatic fall of serum albumin and to a lesser extent rise of globulins are still clearly demonstrable nine to 10 days after operation. This is of interest because most of the earlier investigators confined their period of observation to the first three or four days after trauma (Clark et al., 1947; Cuthbertson and Tompsett, 1935; Frawley, Artz, and Howard, 1955; Frawley, Howard, Artz, and Anderson, 1955; Moore, 1959). Further, it should be noted that the fall in albumin concentration (when expressed in terms of a percentage of the pre-operative level)

TABLE IX

POST-OPERATIVE BLOOD VOLUME CHANGES IN PATIENTS WITH DUMPING SYNDROME AS PERCENTAGE OF PRE-OPERATIVE VALUES

Serial Case No.

\begin{tabular}{l} 
\\
\hline 43 \\
77 \\
78 \\
101 \\
Mean values \\
Mean values for whole partial \\
gastrectomy series
\end{tabular}

${ }^{1}$ Figures in the table are given to the nearest $0.05 \%$.
Six to Nine Months after Operation

\begin{tabular}{|c|c|c|c|c|c|}
\hline \multicolumn{3}{|c|}{10 Days after Operation } & \multicolumn{3}{|c|}{ Six to Nine Months after Operation } \\
\hline Plasma & Blood & Total Red Cell & Plasma & Blood & Total Red Cell \\
\hline $\begin{array}{l}(\%) \\
+6.5^{1} \\
-12.3 \\
+7.0 \\
+10.6 \\
+2.95\end{array}$ & $\begin{array}{l}(\%) \\
+15 \cdot 2 \\
-14 \cdot 1 \\
0 \\
+6.45 \\
+1.9\end{array}$ & $\begin{array}{l}(\%) \\
-7.3 \\
-16.7 \\
-11.9 \\
-3.5 \\
-9.85\end{array}$ & $\begin{array}{l}(\%) \\
-7.6 \\
+13.8 \\
+28.0 \\
-4.4 \\
+7.45\end{array}$ & $\begin{array}{l}(\%) \\
-15.4 \\
+12.3 \\
+21.0 \\
-2.7 \\
+3.8\end{array}$ & $\begin{array}{l}(\%) \\
-25.1 \\
+10.0 \\
+10.2 \\
+0.9 \\
-1.0\end{array}$ \\
\hline$+4 \cdot 3$ & $-2 \cdot 9$ & $-14 \cdot 2$ & +9.0 & $+5 \cdot 3$ & -0.2 \\
\hline
\end{tabular}


TABLE $X$

SERUM PROTEIN CHANGES NINE TO 10 DAYS POST-OPERATIVELY

\begin{tabular}{|c|c|c|c|c|c|}
\hline & & $\begin{array}{l}\text { Mean Post- } \\
\text { operative Values }\end{array}$ & $\begin{array}{l}\text { Mean Pre- } \\
\text { operative Values }\end{array}$ & $\begin{array}{l}\text { Difference of } \\
\text { the Means }\end{array}$ & $\begin{array}{l}\text { Same as } \% \text { of } \\
\text { Pre-operative } \\
\text { Mean }\end{array}$ \\
\hline $\begin{array}{l}\text { Partial gastrectomy series ( } 30 \text { cases) } \\
\text { Concentrations (g./100 ml.) }\end{array}$ & $\begin{array}{l}\text { Total protein } \\
\text { Albumin } \\
\text { Globulins }\end{array}$ & $\begin{array}{l}6.56 \\
3.92 \\
2.64\end{array}$ & $\begin{array}{l}7 \cdot 15 \\
4 \cdot 60 \\
2 \cdot 55\end{array}$ & $\begin{array}{l}-0.59 \\
-0.68 \\
+0.09\end{array}$ & $\begin{array}{r}-8.25 \\
-14.78 \\
+3.53\end{array}$ \\
\hline Total circulating masses (g.) & $\begin{array}{l}\text { Total protein } \\
\text { Albumin } \\
\text { Globulins }\end{array}$ & $\begin{array}{r}172 \cdot 05 \\
104 \cdot 53 \\
70 \cdot 35\end{array}$ & $\begin{array}{r}180 \cdot 70 \\
116 \cdot 97 \\
63 \cdot 72\end{array}$ & $\begin{array}{r}-8.65 \\
-12.44 \\
+6.63\end{array}$ & $\begin{array}{r}-4 \cdot 79 \\
-10 \cdot 64 \\
+10 \cdot 40\end{array}$ \\
\hline $\begin{array}{l}\text { Vagotomy with gastro-enterostomy } \\
\text { Concentrations (g./100 ml.) }\end{array}$ & $\begin{array}{l}\text { Total protein } \\
\text { Albumin } \\
\text { Globulins }\end{array}$ & $\begin{array}{l}6 \cdot 79 \\
4 \cdot 20 \\
2 \cdot 67\end{array}$ & $\begin{array}{l}7 \cdot 42 \\
4 \cdot 79 \\
2 \cdot 65\end{array}$ & $\begin{array}{r}-0.63 \\
-0.59 \\
+0.02\end{array}$ & $\begin{array}{r}-8.67 \\
-12.33 \\
+\quad 0.75\end{array}$ \\
\hline Total circulating masses (g.) & $\begin{array}{l}\text { Total protein } \\
\text { Albumin } \\
\text { Globulins }\end{array}$ & $\begin{array}{r}183 \cdot 75 \\
110 \cdot 50 \\
73 \cdot 25\end{array}$ & $\begin{array}{r}183 \cdot 13 \\
118 \cdot 25 \\
64 \cdot 88\end{array}$ & $\begin{array}{r}+0.62 \\
-7.75 \\
+8.37\end{array}$ & $\begin{array}{l}+0.34 \\
-6.55 \\
+12.87\end{array}$ \\
\hline $\begin{array}{l}\text { Pyloroplasty } \\
\text { Concentrations (g./100 ml.) }\end{array}$ & $\begin{array}{l}\text { Total protein } \\
\text { Albumin } \\
\text { Globulins }\end{array}$ & $\begin{array}{l}7 \cdot 28 \\
4 \cdot 52 \\
2 \cdot 72\end{array}$ & $\begin{array}{l}7 \cdot 96 \\
5 \cdot 32 \\
2 \cdot 64\end{array}$ & $\begin{array}{l}-0.68 \\
-0.80 \\
+0.08\end{array}$ & $\begin{array}{r}8.54 \\
-15.04 \\
+\quad 3.03\end{array}$ \\
\hline Total circulating masses (g./100 ml.) & $\begin{array}{l}\text { Total protein } \\
\text { Albumin } \\
\text { Globulins }\end{array}$ & $\begin{array}{r}191 \cdot 20 \\
119 \cdot 20 \\
72 \cdot 20\end{array}$ & $\begin{array}{r}201 \cdot 00 \\
131 \cdot 40 \\
67 \cdot 40\end{array}$ & $\begin{array}{r}9 \cdot 80 \\
-12 \cdot 20 \\
+4 \cdot 80\end{array}$ & $\begin{array}{r}-4.88 \\
-9.28 \\
+7 \cdot 14\end{array}$ \\
\hline
\end{tabular}

is more pronounced than the fall of its total circulating mass. This is due to the post-operative compensatory rise in plasma volume, following the operative blood loss. The reverse is true of the globulins whose total circulating mass rises to a greater extent than their concentration, also on account of a rise in plasma volume. This rather prolonged post-operative serum protein derangement makes it difficult to believe that the usual explanation in terms of post-traumatic salt retention is really adequate (Moore, 1959; Oszacki, Sowińska, Adamczyk, Marczyńska, and Gedliczka, 1959). As Moore (1959) points out, it would not, in any case, explain the rise in globulins. The prolonged nature of the fall in post-operative albumin acquires an added significance if its preoperative deficit in chronic peptic ulcer patients, as suggested by our findings, is taken into account.

Long-term effects Results of serum protein estimation were available for 17 cases of partial gastrectomy. They are summarized in Table XI. Comparison with the pre-operative figures shows that there was only one statistically significant $(P=0.02)$ change, that of serum globulin concentration, which fell by $12.94 \%$. This change, however, was in the direction of normality, since the pre-operative globulin levels were in excess of normal (Table IV). The total circulating globulin mass returned practically to the pre-operative level. The albumin concentration demonstrated a slight further fall and its total circulating mass a slight rise (due to plasma volume increase); both, however, are not statistically significant.

\section{CONCLUSIONS}

Patients with gastric ulcer usually come to operation underweight (mean deficit, $16.5 \%$ of normal), whereas those with duodenal ulcer tend to maintain their weight within normal limits.

TABLE XI

LONG-TERM POST-OPERATIVE SERUM PROTEIN CHANGES

\begin{tabular}{|c|c|c|c|c|}
\hline $\begin{array}{l}\text { Partial Gastrectomy Group } \\
\text { of } 17 \text { Cases }\end{array}$ & $\begin{array}{l}\text { Mean Post-operative } \\
\text { Values }\end{array}$ & $\begin{array}{l}\text { Mean Pre-operative } \\
\text { Values }\end{array}$ & $\begin{array}{l}\text { Difference of the } \\
\text { Means }\end{array}$ & $\begin{array}{l}\text { Same as } \% \text { of Pre- } \\
\text { operative Mean }\end{array}$ \\
\hline $\begin{array}{l}\text { Concentrations }(\mathrm{g} . / 100 \mathrm{ml} .) \\
\text { Total protein } \\
\text { Albumin } \\
\text { Globulins }\end{array}$ & $\begin{array}{l}6 \cdot 49 \\
4 \cdot 27 \\
2 \cdot 22\end{array}$ & $\begin{array}{l}7 \cdot 12 \\
4 \cdot 58 \\
2 \cdot 55\end{array}$ & $\begin{array}{l}-0.63 \\
-0.31 \\
-0.33\end{array}$ & $\begin{array}{r}-8.85 \\
-6.77 \\
12.94\end{array}$ \\
\hline $\begin{array}{l}\text { Total Circulating masses }(\mathrm{g} .) \\
\text { Total protein } \\
\text { Albumin } \\
\text { Globulins }\end{array}$ & $\begin{array}{r}170 \cdot 60 \\
112 \cdot 20 \\
58 \cdot 35\end{array}$ & $\begin{array}{r}164 \cdot 90 \\
106 \cdot 90 \\
58 \cdot 00\end{array}$ & $\begin{array}{l}-0.31 \\
+5 \cdot 30 \\
+0.35\end{array}$ & $\begin{array}{l}-6 \cdot 77 \\
+5 \cdot 04 \\
+\quad 0.60\end{array}$ \\
\hline
\end{tabular}


In both gastric and duodenal ulcer cases there is a pre-operative deficit of blood volume which is due more to shortage of red cells than to that of plasma. Therefore, these patients tend to be anaemic; the state of anaemia is, however, inadequately and usually insufficiently reflected by the haemoglobin and haematocrit figures.

The red cell deficit is further aggravated by the operative blood loss, and although it is, on the average, made good over the next six to nine months, the initial, pre-operative deficit tends to persist. Patients who received blood transfusion (of the order of 2 pints) at or immediately after partial gastrectomy showed very little operative blood loss and higher total red cell volume levels six to nine months after operation than those operated on without blood transfusion.

No relation was found between the post-gastrectomy post-cibal dumping effects and persistent deficit of blood volume.

Both gastric and duodenal ulcer cases showed a tendency to hypoalbuminaemia pre-operatively. This albumin deficit was more marked when expressed as the total circulating albumin mass than in terms of albumin concentration in the serum because of the concomitant plasma volume deficit. Hypoalbuminaemia was still further aggravated by the post-operative fall in serum albumin levels. Nine to 10 days after gastrectomy serum albumin concentration still remained significantly below the preoperative level, as well as its total circulating mass below the respective pre-operative figure. Six to nine months after gastrectomy, serum proteins tended to return to the pre-operative state, more or less. This return was more complete in terms of total circulating masses than in those of concentrations. Thus, the pre-operative hypoalbuminaemia tended to persist after gastrectomy.

\section{REFERENCES}

Badyl'kes, S. O., and Bygodner, E. B. (1957). K probleme ro i tsentral'noi nervoi sistemy $\mathrm{v}$ regulyatsii belkovogo obmena $u$ bol'nykh iaznvennoi bolezn'iu (Role of the central nervous system in the regulation of protein metabolism in peptic ulcer). Klin. Med. (Mosk.), 35, No. 6, p. 38-42.

Campbell, T. J., Frohman, B., and Reeve, E. B. (1958). A simple, rapid, and accurate method of extracting T-1824 from plasma, adapted to the routine measurement of blood volume. J. Lab. clin. Med., 52, 768-777.

Clark, J. H., Nelson, W., Lyons, C., Mayerson, H. S., and DeCamp, P. (1947). Chronic shock: the problem of reduced blood volume in the chronically ill patient. Ann. Surg., 125, 618-646.

Conti, U., Cortinovis, R., Arisi, C., and Manzini, B. (1957). Comportamento delle proteine ematiche in pazienti affetti da ulcera gastroduodenale, prima e dopo resezione gastrica. Atti Soc. lombarda Sci. med. biol., 12, 443-447.

Cuthbertson, D. P., and Tompsett, S. L. (1935). Note on the effect of injury on the level of the plasma proteins. Brit. J. exp. Path., $16,471-475$.

Davis. H. A., and Isenberg, L. (1953). An improved blood volume method (Evans blue dye) utilizable even in the presence of hemolysis and/or lipemia. J. Lab. clin. Med., 41, 789-795.
Fauvret, R., Hartmann, L., Guénin, P., and Thiébauld, L. (1952) Le retentissement hématologique des gastrectomies: l'anémie protéiprive-étude de 110 cas de gastrectomies. Sang, 23, 745-753.

Frawley, J. P., Artz, C. P., and Howard, J. M. (1955). Muscle metabolism and catabolism in combat casualties; systemic response to injury in combat casualties. A.M.A. Arch. Surg., 71, 612-616.

-, Howard, J. M., Artz, C. P., and Anderson, P. (1955). Investigations of serum protein changes in combat casualties; the systemic response to injury. Ibid., 71, 605-611.

Gibson, J. G., Jr. and Evans, W. A., Jr., (1937a). Clinical studies of the blood volume: I. Clinical application of a method employing the azo dye, "Evans blue", and the spectrophotometer. J. clin. Invest., 16, 301-316.

- - (1937b). Clinical studies of the blood volume. II. The relation of plasma and total blood volume to venous pressure, blood velocity rate, physical measurements, age, and sex in 90 normal humans. Ibid., 16, 317-328.

—, Peacock, W. C., Seligman, A. M., and Sack, T. (1946). Circulating red cell volume measured simultaneously by the radioactive iron and dye methods. Ibid., 25, 838-847.

Hamilton, L. H. (1958). A spectrophotometric method for the determination of Evans blue dye in the presence of hemolysis and turbidity. J. Lab. clin. Med., 52, 762-767.

Hicks, D. A., Hope, A., Turnbull, A. L., and Verel, D. (1956). The estimation and prediction of normal blood volume. Clin. Sci. $15,557-565$.

Hobsley, M., and Dew, E. D. (1958). An extraction technique for the estimation of Evans blue in plasma. J. clin. Path., 11, 451-454.

-, and Le Quesne, L. P. (1960). The dumping syndrome. II. Cause of the syndrome and the rationale of its treatment. Brit. med.J., $1,147-151$.

Inkley, S. R., Krieger, H., and Brooks, L. (1953). A study of methods for the prediction of plasma volume in fifty normal subjects. (An abstract.) J. clin. Invest., 32, 577.

Jarnum, S. (1959). A modified extraction method for determination of Evans blue. Scand. J. clin. Lab. Invest., 11, 332-339.

Lawrence, A. C. K., and Walters, G. (1959). The extraction of Evans blue ( $T$ 1824) from plasma and the measurement of plasma volume. J. clin. Path., 12, 123-127.

Le Quesne, L. P., Hobsley, M., and Hand, B. H. (1960). The dumping syndrome. I. Factors responsible for the symptoms. Brit. med. J., 1, 141-147.

Life Extension Institute of New York City. Tables of Heights and Weights of Adults. Quoted from Documenta Geigy Scientific Tables, 5th edition. (Rev.) J. R. Geigy, S.A. Basle (1959), p.255.

Mallet-Guy, P., Devic, G., and Grangeon, M. (1950). La détermination du volume sanguin dans la pratique chirurgicale. Lyon chir., 45, 780-797.

,-- and Ricard, A. (1954). Séquelles générales de la gastrectomie pour ulcère et perturbations du volume sanguin: efficacité du rétablissement de la masse sanguine. Ibid., 49, 913-930.

-, Ricard, A., and Corréard, L. (1955). Contrôle des indications et prévention des accidents de surcharge de la transfusion sanguine. Analyse de 3,013 déterminations du volume sanguin. Ibid., 50, 137-145.

Moore, F. D. (1959). Metabolic Care of the Surgical Patient, p. 102. Saunders, Philadelphia and London.

Oszacki, J., Sowińska, B., Adamczyk, B., Marczyńska, A., and Gedliczka, O. (1959). Remote results of gastrectomy in peptic ulcer on electrolyte and protein composition of the blood serum. Pol. Przegl. chir., 31, 159-164.

Roberts, K. E., Randall, H. T., Farr, H. W., Kidwell, A. P., McNeer, G. P., and Pack, G. T. (1954). Cardiovascular and blood volume alterations resulting from intrajejunal administration of hypertonic solutions to gastrectomized patients: the relationship of these changes to the dumping syndrome. Ann. Surg., 140, 631-640.

Schrevel, J. de, Lammerant, J., and Visscher, M. de (1955). Poids corporel et détermination du volume sanguin par la méthode des hématies marquées au $\mathbf{P}_{33}$. Arch. int. Physiol., 63, 129-132.

Swan, A., Allen, G. T., and Tanner, N. C. (1959). Blood volume before and after gastrectomy. Gastroenterologia (Basel), 92 , 137-145.

Williams, W. T., and Parsons, W. H. (1958). The indications for blood volume determinations in major surgical procedures. Surg. Gynec. Obstet., 106, 435-440. 